\title{
The Rights for Legal Protection Guarantee for Nurse Management Who was Victimized When Doing Medical Treatments Towards Patients
}

\author{
Sulis Setyowati ${ }^{1}$, Ardiyan $^{2}$, Naib $^{3}$ \\ Faculty of Law Universitas Pamulang ${ }^{1}$, Faculty of Law Universitas Pamulang ${ }^{2}$, Faculty of Law \\ Universitas Pamulang ${ }^{3}$ \\ \{lismadiun2014@gmail.com¹, ardiyanos.mbojo@yahoo.com²,naib.lipi@gmail.com³
}

\begin{abstract}
The position of nurses as health workers plays a strategic role in their contribution for improving health status and providing nursing care and does not have the authority to take medical action except in emergencies and there is delegation from doctors. Therefore, nurses in carrying out medical treatment,they must get the right for legal protection guarantee that regulated in the legislation in the field of health, in the field of nursing and related legislation. The research is a normative legal research based on secondary data to be processed and analyzed qualitatively. The results and analysis that the fulfillment of the right to guarantee legal protection for nurses who experience victimization when conducting medical treatment to the patients, and it can be done through legal mediation (non-litigation) and litigation legal efforts.
\end{abstract}

Keywords: The rights, Legal Protection guarantee, Nurses, Victimization, Medical reatments, Patients.

\section{Introduction}

Human Rights is a term commonly used to replace the term human rights. Besides, some use the term fundamental rights or basic rights. God Almighty has given human rights from the birth, namely human rights inherent in the presence of these rights through the existence of their dignity as human beings. In accordance with dignity of man which is primus interpret contained in international human rights documents. All international conventions or conventions and protocols state that human dignity can be protected, guaranteed and respected through all rights that fall into the category of human rights.

Human Rights are also understood as the basic rights of a person as a human being (human being). If human rights are considered as something that is common to all people throughout the world (universal, applicable everywhere) and is applied equally to all people (egalitarian, the same for everyone). Therefore, human rights are moral principles that set certain standards of human behavior and these rights are protected as legal rights both in national law and international law. The essential value of human rights is to protect the basic rights of citizens contained in the constitution. In the development of history, human rights are always related to the constitution. According to the teachings of constitutionalism, the limitation and regulation of state power is intended as protection, respect and fulfillment of human rights. Therefore, human rights are crucial found in the text of the Constitution of the modern state. The international document related to the protection of victims' rights is the UN Resolution on Protection of the Human Rights of Victim of Crime and Abuse of Power 1990. Based on the international document, the implementation stage requires a complete understanding of 
victims of crime must be based on an understanding of the development of knowledge about victim of crime (victimization).

The Arrangement of Human Rights in the Opening of the 1945 Constitution of the Republic of Indonesia divides 4 (four) groups which contain 37 provisions namely: economic, social and cultural rights (economic and social rights), civil and political rights (civil rights), non-legal provisions derogable rights, rights to development and other special rights as well as state responsibilities and human rights obligations. The international document related to the protection of victims' rights is the UN Resolution on Protection of the Human Rights of Victim of Crime and Abuse of Power 1990. Based on the international document, the implementation stage requires a complete understanding of victims of crime must be based on an understanding of the development of knowledge about victim of crime (victimization).

The Arrangement of Human Rights in the Opening of the 1945 Constitution of the Republic of Indonesia divides 4 (four) groups which contain 37 provisions namely: economic, social and cultural rights (economic and social rights), civil and political rights (civil rights), non-legal provisions derogable rights, rights to development and other special rights as well as state responsibilities and human rights obligations. The responsibility of the state or government through the judiciary in providing the right to guarantee legal protection can be obtained in the law enforcement system. Law enforcement according to Lawrence M. Friedman is " part of the legal system. Without law.

The Arrangement of Human Rights in the Opening of the 1945 Constitution of the Republic of Indonesia divides 4 (four) groups which contain 37 provisions namely: economic, social and cultural rights (economic and social rights), civil and political rights (civil rights), non-legal provisions derogable rights, rights to development and other special rights as well as state responsibilities and human rights obligations. The international document related to the protection of victims' rights is the UN Resolution on Protection of the Human Rights of Victim of Crime and Abuse of Power 1990. Based on the international document, the implementation stage requires a complete understanding of victims of crime must be based on an understanding of the development of knowledge about victim of crime (victimization).

The Arrangement of Human Rights in the Opening of the 1945 Constitution of the Republic of Indonesia divides 4 (four) groups which contain 37 provisions namely: economic, social and cultural rights (economic and social rights), civil and political rights (civil rights), non-legal provisions derogable rights, rights to development and other special rights as well as state responsibilities and human rights obligations. The responsibility of the state or government through the judiciary in providing the right to guarantee legal protection can be obtained in the law enforcement system. Law enforcement according to Lawrence M. Friedman is " part of the legal system. Without law enforcement, the material rules of law become a pile of paper and the coveted state of law is only a dream. As part of the legal system, law enforcement is closely related to the elements of the legal system consisting of legal structure, legal substance, and legal culture.

" The legal structure consists of law enforcement officers, legal material is a set of laws and regulations, and the legal culture is a living law adopted by the community the role of law enforcement is very necessary in fulfilling the right to legal protection to its citizens, especially experiencing victimization while carrying out medical treatment during pandemic COVID -19. Like the incident of persecution have been experienced by nurses at the Haulussy County General Hospital in the name of Jomima Orno who was allegedly persecuted by 3 (three) Hasan Keiya's family members, after refusing the family's request. The family requested that Hasan be buried without health protocol in a corona special burial 
park in the village of Hunut, Teluk Ambon, Maluku. Hasan Keiya is a patient who died after being treated at RSUD dr. M. Haulussy Ambon on Friday, June 262020 morning at around 07.30 East Indonesian Time in front of the corpse room of covid-19 patients in RSUD dr. M. Haulussy.

Police Commissioner Leo Simatupang as the Chief of Police Resta of the Ambon Island said on Saturday morning, June 27, 2020 that the police was coordinating with Bhayangkara Hospital regarding the results of the visum et repertumJominaOrno. After the post mortem was received by members of the Satreskrim there were injuries to several parts of the victim's body. The case plan for the cases of mistreatment of nurses and cases of forced corona corpses will take place next week after all cases have been completed on Saturday night. Seeing these events, the position of nurses as health workers is very strategic role in their contribution for improving health status and providing nursing care and does not have the authority to take medical action except in emergencies and there is delegation from doctors. Based on background of the problem, the following problems can be formulated:

a) What are the forms of legal protection received by nurses in carrying out medical service tasks?

b) How is the fulfillment of the right to guarantee legal protection for nurses who experience victimization when conducting medical treatment to patients?

\section{Research Methods}

This type of research is a normative legal research that is legal research that begins with normative premises that only recognize secondary data, the type of data (legal material) isa) primary legal material in the form of legislation in the fields of health, nursing, and human rights ; b) secondary legal materials, namely research results in the field of health and nursing; c) tertiary legal material such as a legal dictionary used to explain definitions relevant to the topic of study under study. Based on the data, it is then processed and analyzed qualitatively, because qualitative legal normative research is research that refers to the legal norms contained in legislation.

\section{Theoretical Studies}

\subsection{Legal protection}

Wilhelm Lundsted in Antonius Sujata, the legal philosopher of the flow of realism said that the law is nothing (law is nothing) which defines the law as conventional believers who interpret the law as a rule of human behavior if not obeyed will provide sanctions against the perpetrators, the law only meaningful after being upheld. Without enforcement, law is nothing. What gives meaning to the law is law enforcement officials and the community.

Related to the enforcement of human rights, legal culture is a suggestion of control over the rules and institutions related to the enforcement of human rights. This is important, so that the existing rules on protecting human rights can be implemented to prevent violations of human rights. In the Indonesian Encyclopedia, law is a set of rules, regulations, rules, both written and unwritten, which determine or regulate relations between members of the community. Maria Farida Indrati S. argues that "a norm can be called as abstract legal norms 
means legal norms that look at somebody's action that has no limitation in terms of unconcrete, meanwhile abstract public legal norms is legal norms that havebeen intended to and for abstract action (unconcrete) ".

It should be kept in mind that however the respect and fulfillment of human rights is a basic human right and society is the benchmark for the achievement of film, order, security; so the determination of the conditions mentioned above must be done strictly. According to Philip Hardjo there is a form of legal protection for the people which is divided into 2 (two), namely:

a) Preventive legal protection means that people are given the opportunity to submit their opinions before a government decision gets a definitive form that aims to prevent disputes.

b) Repressive legal protection aimed at resolving disputes.

The right to guarantee legal protection is a guarantee given by the state to all parties to be able to exercise their legal rights and interests in their capacity as legal subjects. According to Soetoprawiro, legal protection is, "an effort from the authorities to provide guarantees and facilities in such a way that every citizen or all citizens can actualize their rights and obligations optimally in a calm and orderly manner.

\subsection{Nurses}

Nurses as professionals in the field of health services, as stipulated in Article 1 paragraph (2) of Law Number 36 of 2014 concerning Health Workers "Assistant Health Workers are everyone who devotes themselves in the health field and has knowledge and or skills through education in the field health under diploma level 3 (three) ". Provisions in the Regulation of the Minister of Health Number. HK.02.02 // Menkes / 148 / I / 2010 concerning Licensing and Organization of Nurse Practices Article 1 number (1) referred to as a nurse is "someone who has graduated from nurses education both at home and abroad in accordance with applicable laws and regulations" . Nurses according to Sri Praptianingsih have functions including independent functions, interdependent functions, and dependent functions namely: authority, competence and nurses' code of ethics in health services according to the professional standards and the Indonesian nurse's code of ethics. The authority of nurses is the right of autonomy to carry out nursing care based on ability, level of education and position of health facilities. The authority of nurses is to perform nursing care covering healthy and sick conditions.

\subsection{Victimization}

The problem of victims of crime (victim rights) according to ArifGosita is "those who suffer physically and spiritually as a result of the actions of others, who seek fulfillment of the interests of themselves or others, which is contrary to the interests and rights of those who suffer".

\subsection{Patient}

Explanation of patients in accordance with the provisions of Article 1 paragraph (4) of Law Number 44 Year 2009 Concerning Hospitals, what is meant by Patient is every person whoconsults his/ her health problems to obtain the necessary health services, both directly and 
indirectly at the Hospital .

\section{Results and Analysis}

Forms of Legal Protection Received by Nurses in Carrying Out Medical Service Tasks Hospital as one of the health service facilities is apart of the health resources that are indispensable in supporting the implementation of health efforts. The delivery of health services in hospitals has very complex characteristics and organizations. Different types of health workers with their scientific devices interact with each other. Medical science and technology are developing very rapidly which must be followed by health workers in the framework of providing quality services, making the complexity of the problems in the Hospital.

Based on the incidents of persecution experienced by nurses at the Haulussy Regional General Hospital on behalf of JomimaOrno who were allegedly mistreated by 3 (three) Hasan Keiya family members, after refusing the request of the family of the patient who died after being treated at RSUD dr. M. Haulussy Ambon the problem of forced corona corpse collection. The incident shows that JomimaOrno as a victim of a crime cannot directly take the right to guarantee legal protection, without going through a legal process. In line with BambangWaluyo's opinion that: At the beginning of a particular criminal process, the victim concerned submits or makes a report or complaint. The perpetrators of criminal acts are further processed through investigation, investigation, prosecution, examination, decision and implementation of court decisions. In the process, the victim can be a witness who can incriminate the suspect or defendant. Actually based on Article 98 to Article 101 of the Criminal Procedure Code (KUHAP), the victim and other injured people can demand compensation, but in practice it is not effectively applied. Mechanism demands for compensation, of course, must be in accordance with the provisions of the Criminal Procedure Code, its implementing regulations and other laws.

Legal protection is basically a legal effort to provide protection for the human rights of every human being harmed by another party. The purpose of giving legal protection is so that a person can enjoy the legal rights he has obtained. In the context of the patient's relationship with the doctor, the patient has the right to legal protection both in the process and after the end of the relationship. One of the legal protections that guarantees the health of every person is the entry into force of Law No. 36 of 2009 concerning Health (hereinafter referred to as the Health Act) in Article 5 explains that everyone is given the right to quality, safe and affordable health services. A patient has the right to obtain good health services by the parties handling it which is also regulated in Article 9 paragraph (1) of the Health Act, so it has become an obligation for doctors and health workers to realize and improve public health. The effort of health workers is the most important thing to achieve the goals to be achieved in the article. Therefore, the forms of legal protection that can be accepted by nurses in carrying out medical treatments, include:

a) Article 4 letter c of Law No. 36 of 2014 concerning Health Workers, states that the Government and Regional Governments are responsible for: protection of Health Workers in carrying out practices.

b) Article 36 of Law No. 38 of 2014 concerning Nursing: Nurses in implementing Nursing Practices are entitled: (1) obtain legal protection as long as carrying out their duties in accordance with service standards, professional standards, operational 
procedures standards, and the provisions of the legislation; (2) obtain true, clear and honest information from the Client and / or his family; (3) receive service fees for Nursing Services that have been provided; (4) reject the wishes of the Client or other parties that conflict with the code of ethics, service standards, professional standards, standard operating procedures, or the provisions of the legislation; and (5) obtain work facilities in accordance with the standards.

c) Article 9 of Law Number 4 of 1984 concerning Communicable Diseases. To certain officers who carry out outbreaks as referred to in Article 5 paragraph (1) may be given an award for the risks borne in carrying out their duties.

d) Article 14 of Law Number 4 of 1984 concerning Communicable Diseases. Legal protection for health workers can also be provided through criminal charges to the public who are still not disciplined to implement protocols for controlling infectious diseases that have an impact on the transmission of health workers or even lead to the death of health workers or other people who are exposed. The disorderly conduct of the Covid-19 countermeasure health protocol standard can be said to meet the element of deliberately hindering the implementation of countermeasures for the contagious disease of Covid-19.

e) Article 17 of Law Number 39 of 1999 concerning Human Rights. The right to justice that everyone, without discrimination, has the right to obtain justice by submitting applications, complaints and lawsuits, both in criminal, civil and administrative matters and tried through a free and impartial judicial process, in accordance with procedural law that guarantees examination objective by honest and fair judges to obtain fair and correct decisions.

f) Article 5 paragraph (1) letter a of Law Number 31 of 2014 concerning Amendment to Law Number 13 of 2006 concerning Protection of Witnesses and Victims, that Witnesses and Victims are entitled to protect their personal, family, and property security, and are free from threats relating to the testimony that will be, is being, or has been given.

g) Regulation of the Minister of Health of the Republic of Indonesia Number 26 Regarding Regulations for Implementing Law Number 38 Year 2014 Regarding Nursing, namely; 1) Article 35 paragraph (1) letter a in carrying out nursing practice, nurses have the right to obtain legal protection as long as they carry out their work in accordance with the Professional Standards, service standards, and operational procedure standards, and the provisions of legislation; 2) Article 35 letter e: refuse the wishes of the client or other parties that are contrary to the code of ethics, service standards, professional standards, standard operating procedures, or provisions of laws and regulations; 3) Article 35 letter g: obtains protection for occupational safety and health, treatment in accordance with human dignity and values, morals, decency, and religious values.

h) Legal protection for nurses who perform medical actions in the context of carrying out governmental duties based on the Minister of Health Regulation Number 2052 / MENKES / PER / X / 2011 concerning Medical Practice Permit and Medical Practice Implementation, especially in Article 23 which explains that "medical actions undertaken by nurses must have written authority delegated from a doctor".

Fulfillment of the Right to Guaranteed Legal Protection for Nurses Who Experience Victimization when Performing Medical Treatment on Patients The urgency of hospitals in ensuring legal protection for doctors and health workers so as not to cause medical errors in 
dealing with patients, as well as patients get legal protection from the responsibilities of the hospital and doctor / health worker. The role and function of the hospital as a place to conduct professional medical services will be closely related to 3 (three) elements which consist of: 1) Quality elements that are guaranteed quality; 2) The element of profit or benefit reflected in the quality of service; and 3) laws governing general medical and / ormedical hospitals.

Hospital responsibilities in relation to responsibilities to personnel. Legal cases in medical services generally occur in hospitals where health workers work. According to the Decree of the Minister of Health of the Republic of Indonesia Number: 722 / Menkes / SK / XII / 2002 concerning Guidelines for Hospital Internal Regulations (hospital by laws), that a hospital is essentially one that can be grouped into: medical services in a broad sense involving promotional activities, preventive, curative, and rehabilitative, education and training of medical personnel, medical research and development. Based on these provisions there are basically 4 (four) sections relating to the responsibilities of the hospital as a medical service, namely: (1) responsibility for personnel: (2) professional responsibility for quality; (3) responsibility for facilities / equipment: (4) responsibility for building security and maintenance. Because of that efforts to fulfill the right to guarantee legal protection for nurses who experienced victimization while doing medical treatment to patients, namely:

a) Mediation (non-litigation) remedies are regulated in Article 29 of Law Number 36 Year 2009 regarding Health. Settlement of complaints or disputes through mediation must be done first, this is adjusted to the provisions of Article 29 of Law Number 36 Year 2009 concerning Health which confirms among other things: in the case of health personnel suspected of negligence in carrying out their profession, such negligence must be resolved first through mediation.

b) Litigation legal remedies, the interests of victims / witnesses of victims represented by Investigators through complaints of criminal acts and / or represented by Public Prosecutors in their indictments and claims including the merging of compensation claims.

c) Compensation claim submitted to the suspect / defendant, combined or examined and decided at the same time in the examination and decision of the criminal case that was charged to the defendant and in the form of a decision.

d) For non-material losses, namely immaterial losses, they must be forced to file again with their own ordinary civil suit, which may take a long time.

e) In each of its civil decisions, the victim / plaintiff in the merger of the compensation case is represented by the Public Prosecutor.

\section{Conclusion and suggestion}

Based on the description in the results of the analysis that conclusions can be drawn as follows:

a) The forms of legal protection received by nurses in carrying out their medical service duties are clearly regulated in the provisions of the articles in the laws and regulations in the field of health and nursing and specifically in the relevant laws and regulations.

b) Fulfillment of the right to guarantee legal protection for nurses who experience victimization when conducting medical treatment against patients, can be done through legal mediation (non litigation) and litigation legal efforts, the interests of victims or witnesses of victims represented by Investigators through complaints of criminal acts 
and or represented by the Public Prosecutor in the indictment and claim including the merger of the claim for compensation.

From the legal problems that occur and the conclusions mentioned above can be given advice, as follows:

a) Nurses as Health Workers who suffer from victimization while carrying out government duties in handling co-19 patients can submit complaints / reports to the police as investigators and investigators.

b) Hospitals and nursing organizations should provide legal assistance facilities to health workers when providing health services and or nursing care.

\section{References}

[1] Rahayu, HukumHakAsasiManusia, BadanPenerbitUniversitasDiponegoro, Semarang, 2015, hlm. 1.

[2] Adnan BuyungNasution, ArusPemikiranKonstitusionalisme: Hak Asasi Manusia dan Demokrasi, Kata Hasta Pustaka, Jakarta, 2007, hlm. 113.

[3] A. Ahsin Thohari, Hak Konstitutional dalam Hukum Tata Negara Indonesia, Erlangga, Jakarta, 2016, hlm. 2.

[4] Jimly Asshiddiqie, Menuju Negara Hukum yang Demokratis, Bhuana Ilmu Populer, Jakarta, 2009, hlm. 414-415.

[5] H. SiswantoSunarso, ViktimologidalamSistemPeadilanPidana, SinarGrafika, Jakarta, 2012, hlm. 75 .

[6] Jimly Asshiddiqie, PengantarIlmuHukum Tata Negara, (Jakarta: RajawaliPers, 2016), hlm. 364.

[7] Wan, Perawat di Ambon Dianiaya setelah Urus Jenazah Corona, https://www.kupasonline.com/2020/06/perawat-di- ambon-dianiaya-setelah-urus.html, diakses Selasa, 30 Juni 2020, pukul 21.16 WIB

[8] Ta'adi, Hukum Kesehatan Pengantar Menuju Perawat Profesional, Jakarta: Kedokteran EGC, 2009, hlm. 20, dalam Imelda Katrina Kowaas, Kajian Yuridis Terhadap Status dan Perlindungan Hukum Perawat dalam Memberikan Pelayanan Terhadap Pasien, Lex Et Societatis Volume VII/No. 2/Feb/2019, hlm. 112, e-journal.unsrat.ac.id, diakses Selasa, 30 Juni 2020, pukul 13.22 WIB.

[9] Amiruddin dan H. Zainal Asikin, Pengantar Metode Penelitian Hukum Edisi Revisi, RajaGrafindo Persada, Jakarta, 2016, hlm. 32-33.

[10] H. Zainuddin Ali, Metode Penelitian Hukum, SinarGrafika, Jakarta, 2016, hlm. 105.

[11] H. Muladi, Hak Asasi Manusia Hakekat, Konsep dan Implikasinya dalam Perspektif Hukum dan Masyarakat, RefikaAditama, Bandung, 2009, hlm. 46-47.

[12] Emanuel Sujatmoko, IndriaWahyuni, Bagus Oktavia Abrianto, Inter Regional Government Cooperation: Administrative Law Perspective, Jurnal Hukum Internasional-Indonesian Journal of International Law, Regional Integration IV, Volume 14 Number 1 October 2016, Center for International Law Studies Faculty of Law University of Indonesia, pages: 37.

[13] Rahayu, Hukum Hak Asasi Manusia, Badan Penerbit Universitas Diponegoro, Semarang, 2010, hlm. 29.

[14] Edita Diana Tallupadang, Yovita Indrayati dan Djoko Widyarto JS, Perlindungan Hukum Bagi Tenaga Perawat yang Melakukan Tindakan Medik dalam Rangka Menjalankan Tugas Pemerintah Terutama Dikaitkan dengan Peraturan Menteri Kesehatan Nomor. 2052/Menkes/Per/X/2011 Tentang Praktik Kedokteran dan Pelaksanaan Praktik Kedokteran, hlm. 22, journal.unika.ac.id., diakses Selasa, 30 Juni 2020, pukul 11.55 WIB. 